\title{
東京都市圏物資流動調査による空間相関を 考慮した物流施設立地選択モデルの検討
}

\author{
兵藤 哲朗 1 坂井 孝典 $2 \cdot$ 河村 和哉 3 \\ 1正会員 東京海洋大学教授 海洋工学部流通情報工学科（†135-8533 東京都江東区越中島2-1-6) \\ E-mail: hyodo@kaiyodai.ac.jp
}

2非会員 Ph.D. Candidate, Department of Urban Planning and Policy, University of Illinois at Chicago

(412 South Peoria Street, Room 215, MC 348, Chicago, IL 60607)

E-mail: tsakai3@uic.edu

3非会員 Associate Professor, Department of Urban Planning and Policy, University of Illinois at Chicago

(412 South Peoria Street, Room 215, MC 348, Chicago, IL 60607)

E-mail: kazuya@uic.edu

\begin{abstract}
首都圈では三環状高速道路ネットワークの概成が間近であり，近年，新規供用インターチェンジ (IC) 付近の大型物流施設立地が目立っている。このような物流施設立地動向を予測する有効なツールの一つが 立地選択モデルであり，これまでも計画立案支援のために用いられてきた。

本研究は, 最新の第五回東京都市圈物資流動調查（2013年実施）結果を用いて, 物流施設立地選択モデ ルの精度向上を検討している，具体的には，空間ラグモデルと空間誤差モデルの，いわゆる空間相関を前 提としたモデルを中心に，その詳細な特性把握とともに，説明力の高い分析手順について検討した。 また， 説明変数に, 約 $1 \mathrm{~km}$ 四方の3次メッシュデータを用いたことも本分析の特徴である. 分析結果から, 空間 相関を考慮したモデルには，十分な精度向上が期待できることが確認された。
\end{abstract}

Key Words : spatial location choice model, mesh data, spatial autoregressive model, logistics facility

\section{1. はじめに}

首都圈では三環状の高速道路ネットワークの概成が間 近となり，それに伴う物流施設の新規立地や機能更新が, 都県を始めとする関係自治体の交通計画や都市計画にお ける喫緊の課題となっている，それらについて実態を把 握し，将来動向を見定めるため，東京都市圈交通計画協 議会は，第四回（2003年）・第五回（2013年）東京都市 圈物資流動調査を実施し，物流施設の立地動向について 分析を進めてきた. 大型トラックの経路分析や，端末物 流調査なども含まれる同調査体系の中核を担うのが，物 流施設の立地選択モデルであり，第四回調査でも新規開 業の圈央道周辺の物流施設立地ポテンシャルの推計が行 われた。

本稿では，上記調査でも用いられた，物流施設の立地 選択モデルの精度向上を図るため, 主に, 3次メッシュ

$($ 約 $1 \mathrm{~km} \times$ 約 $1 \mathrm{~km})$ データを用いた，メッシュ間の空間 相関を考慮した離散選択モデルの検討を行う。これは, メッシュは緊密に隣接した空間データなので，空間相関
を導入する効果が高いことが想定されるためである.ま た，空間相関のみならず，種々のモデル適用結果の比較 検討を通じて, より適切な分析技法の確立について知見 を得ることを最終的な目的とする。

\section{2. 既往研究のレビューと本研究の位置づけ}

\section{(1) 本稿で対象とするモデル}

交通計画における立地選択モデルとしては，主にオペ レーションズ・リサーチの分野で用いられる Alfred Weber ${ }^{1)}$ の理論に基づく最適化手法を用いるものと, Daniel McFadden $\left.{ }^{2}\right)$ にる離散選択モデルを用いるものが一般的 である. 前者は, 予め定められた効用関数を最大化する 立地の特定が目的であるのに対し, 後者は, 既存の立地 データに基づき，効用関数，及び，主な立地要因を特定 し, 因果関係の確認, 並びに, 将来の立地の予測のため に用いられる. 前者は特定施設の立地に関する意思決定 支援のために用いられるが，特定の地域を対象とした都 市・交通モデルにおいては，後者の使用が一般的である. 
(例えば，Urban Sim³)，IUMASS4等)

本稿は，離散選択モデルを対象とし，都市貨物交通需 要に大きな影響を与える物流施設に焦点を当て，計画立 案支援を目的とした立地モデルの適切な構築手法を模索 するものである.

\section{(2) 既往研究のレビュー}

既往研究において，主に都市物流施設を対象として立 地選択予測モデルを構築するものは少なく, 東京都市圈 を対象としたものに限られている，例えば，萩野らすは 2003年に実施された第四回東京都市圈物資流動調査のデ 一タを用い，広域物流施設を対象とした Multinomial Logit (MNL)モデルの推定を行い, それを用いて, 東京都市圈 における将来の物流施設の立地ポテンシャルを推定して いる. Nguyen \& Sano6は同じく, 第 4 回東京都市圈物資 流動調查のデータを用い，空間相関を考慮した Mixed Logit モデルを，物流施設の立地選択を対象として推定 している.また, 萩野ら ね, 物流施設及び工場の立地 モデル(MNL)と，商業施設モデル，及び，地価モデルを 組み合わせ，人口分布の変化に伴う，将来の物流施設の 分布をシミュレートしている. 一方で, 予測モデルを構 築するものではないが，特定の指標（アクセシビリティ， 空間的集積, 地価等）と物流施設の立地の相関を分析寸 るものとして, Woudsma et al. ${ }^{8}$, van den Heuvel et al.9), Verhetsel et al. ${ }^{10)}$ の研究がある.

居住地，及び，事業所一般を対象とした既往研究は多 く，特に，空間相関が存在する場合には，MNLにおけ る IIA 仮定が満たされないことから，空間相関を前提と したモデル手法が提案されている．全般的なレビューは， 堤・瀬谷 ${ }^{11)}$ に詳しいが，例えば， Miyamoto et al. ${ }^{12)}$ は空間 相関を確定項，及び，誤差項において考慮した Mixed Logit モデルを提案し，仙台市における居住地選択デー タを用いてモデルを推定している。また，前述の Nguyen \& Sano ${ }^{13)}$ は，誤差項において空間相関を考慮する 他，確定項において他の事業所との距離を考慮した上で, 同様に MixedLogit モデルを推定している.（詳しくは後 述するが，確定項において空間相関を考慮するものを空 間ラグモデル，誤差項において空間相関を考慮するもの を空間誤差モデルと呼ぶ。)

また，空間相関をネスト（入れ子）構造を用いて考慮 するものとして， Bhat \& Guo ${ }^{144}$ ，及び， Sener et al. ${ }^{15}$ がある. Bhat \& Guo は一般化極值(GEV)モデルを用いて, 隣接す るエリア間の相関関係をネスト構造で考慮した Spatially ComelatedLogitモデルと，更にそのパラメータが多変量正 規分布に従うとした Mixed Spatially Comelated Logit (SCL)モ デルを提案し, Dallas-Fort Worth 都市圈の 236 世帯のデー タを用いて，モデルを推定している. 更に, Sener etal.で は, Bhat \& Guo の SCL モデルを拡張し，ネスト構造を隣
接するエリア間に限定せず，全エリア間に設定している

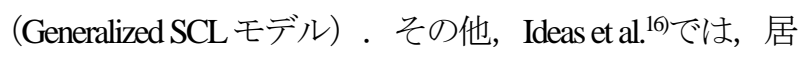
住地選択を対象とした NestedLogitモデル，及び，居住地 と就業地の同時選択を対象とした Cross-Nested Logit モデ ルの推定を試みている.

\section{(3) 本研究の位置づけ}

上記の通り, 既往研究においては, 空間相関に対応す るために，空間ラグモデル・空間誤差モデル，或いは, Nestedモデルを含むGEVモデル，そして，それらとMixed モデルの組み合わせ等が提案されており，一部の手法は 物流施設の立地選択にも応用されている. 本稿は, 特に 空間ラグモデル・空間誤差モデルに焦点を当て, これら 既往研究によって提供された知見を活かしつつ, 3次メ ッシュという, 詳細かつ高、空間相関が想像される最新 の物流施設立地データに応用し, モデル特性, 及び, 妥 当性・有効性を検証するものである．それらの分析を通 じて，実用性があり，説明力の高い立地選択モデルを提 案することを本研究の主目的とする。なお，首都圈を網 羅する広範囲の3次メッシュデータに対して, 空間相関 の概念を導入した物流施設立地選択分析を行うことに, 本研究の新規性を認めることができると考えている.

\section{3. 物流施設立地選択モデルの比較検討}

\section{(1) 分析データの概要}

本稿では, 第五回東京都市圈物資流動調査における, 物流施設の立地箇所のデータを用いる. 同データは2013 年度に東京都市圈交通計画協議会により実施された調査 で，東京都・埼玉県・神奈川県・千葉県・茨城県中南 部・栃木県南部・群馬県南部を対象地域として, 合計約 44,000の事業者から回答を得ている 貨物の搬出入，施設の機能，施設の立地特性などである. 物流施設の立地動向を分析対象とするため，本分析では， 使用データとして，敷地面積が3,000m²以上で，2000年以 降に立地した大型物流施設を分析対象とし, 該当する 328の物流施設の立地データを扱うこととする.

\section{（2）説明変数の特性}

説明変数には，第四回東京都市圈物資流動調查で検討 された立地選択モデルの)と同様，3次メッシュ（約 $1 \mathrm{~km} \times$ 約 $1 \mathrm{~km})$ 単位に土地利用条件や，インターチェンジ (IC) アクセス距離などの交通条件を設定している，道路距離 については，道路交通センサスによる配分計算用のネッ トワークを用いて最短経路を探索している．また，「全 製造業近接性」「業務地近接性」変数は, 各々以下の式 で算出されるアクセシビリティ変数である. 
$i$ 番目メッシュの全製造業近接性 $\left(A C M_{i}\right)$ ：

$$
A C_{-} M_{i}=\sum_{j=1}^{J} M_{j} \exp \left[-\ln \left[d_{i j}\right]\right]
$$

$M_{j}: j$ 番目メッシュの工業出荷額（万円，H22工

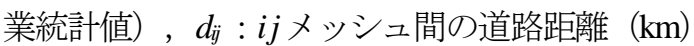
$i$ 番目メッシュの業務地近接性 $\left(A C \_B i\right)$ :

$$
A C_{-} B_{i}=\sum_{j=1}^{J} B_{j} \exp \left[-0.5 \cdot \ln \left[d_{i j}\right]\right]
$$

$B_{j}: j$ 番目メッシュの従業人口（人， H21 経済セ ンサス值)

なお，アクセシビリティの道路距離に係るパラメータ值 は，発地制約型のグラビティモデル（集計ロジットモデ ル）の推定結果を用いている.

地価は，メッシュ内の公示地価（2013年）について， 帰属する用途地域条件により推計を行った。詳細は本稿 の付録（補注）を参照されたい. そのため，公示地価の ないメッシュ（山林など） は分析対象から除かれること になる，その結果，合計で17,961のメッシュがモデル構 築のために用いられることになった.

図-2〜10にモデルに用いた説明変数の階級図を示す.

\section{（3）各種立地選択モデルの比較}

準備された変数を用いて，まず基本的な立地選択モデ ルの推定を行う。メッシュの総数が17,961あるので，最 初に，全メッシュを選択肢とする，サンプル数328の MNLモデルの推定を行う。第四回東京都市圈物資流動 調査では，選択肢数が莫大なため，200個程度の選択肢 サンプリングを行っていたが，Rのマトリックス計算機 能を用いることで，全選択肢を扱っても標準的なPCで，

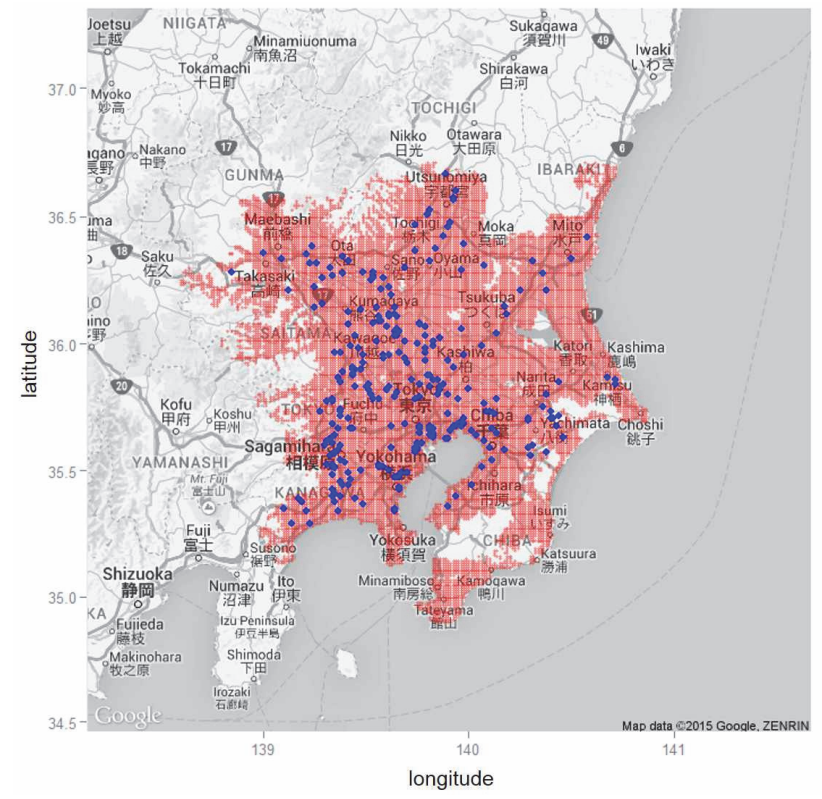

図-1 分析対象のメッシュ（赤）と物流施設（青）の位置

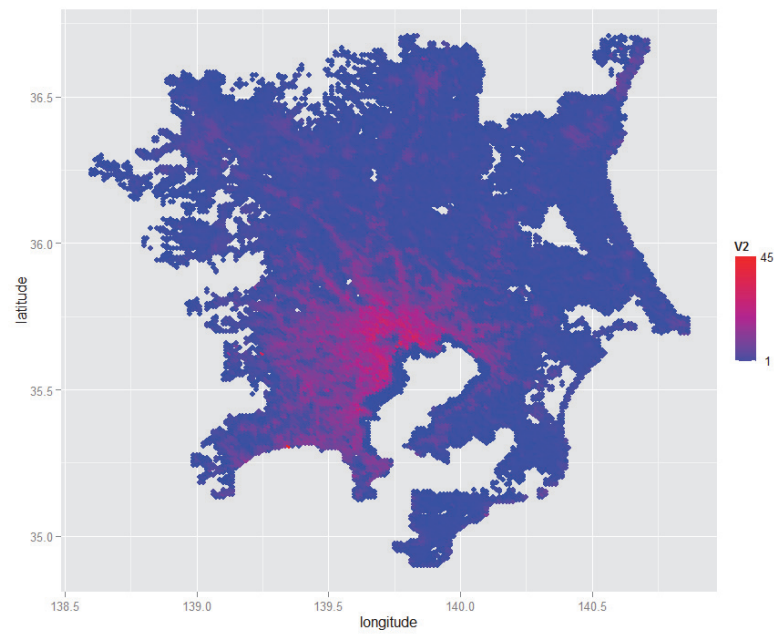

図-2＼cjkstart説明変数［人口密度 $]$ の階級図

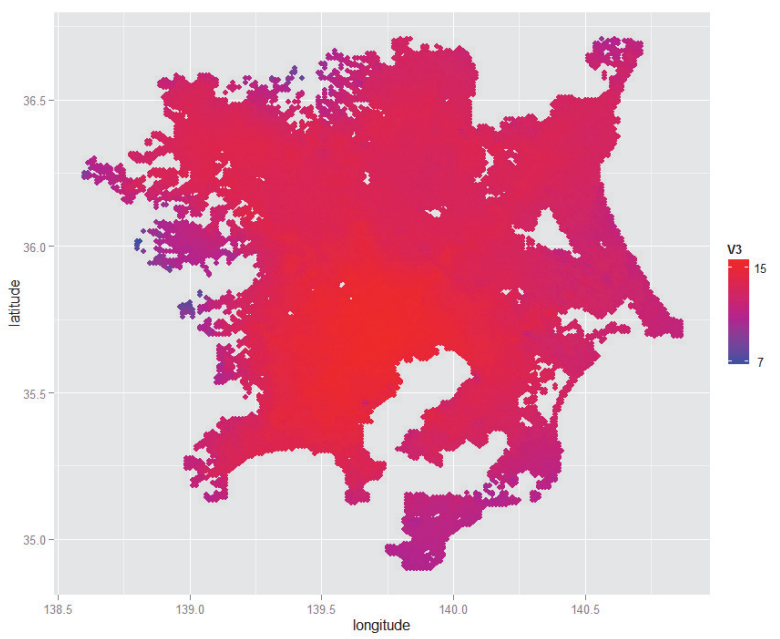

図-3 説明変数 $[\ln ($ 労働力人口) $]$ の階級図

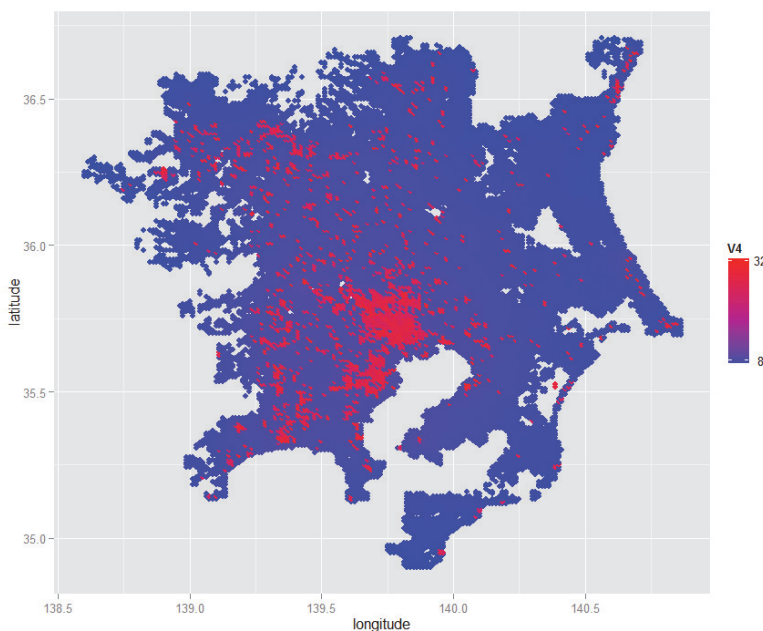

図-4 説明変数 $[\ln ($ 全製造業近接性 $)]$ の階級図 


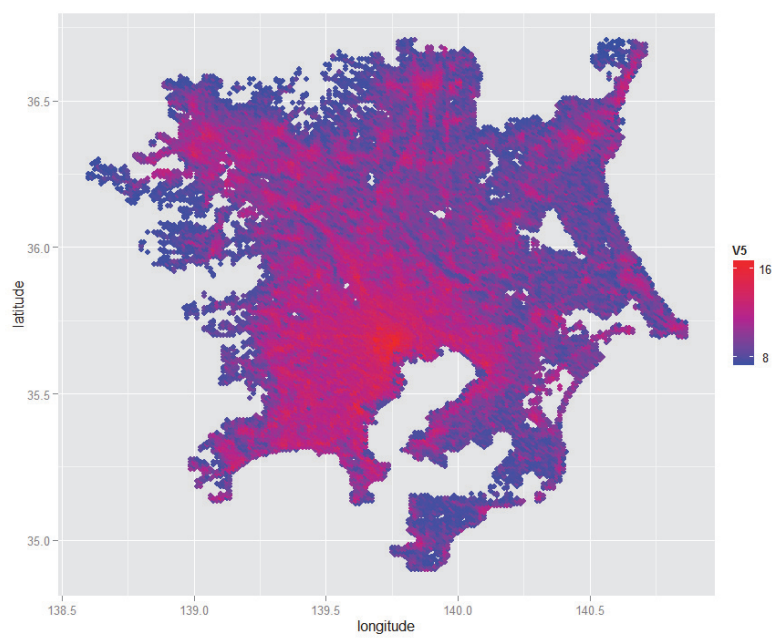

図-5 説明変数 $[\ln ($ 業務地近接性 $)]$ の階級図

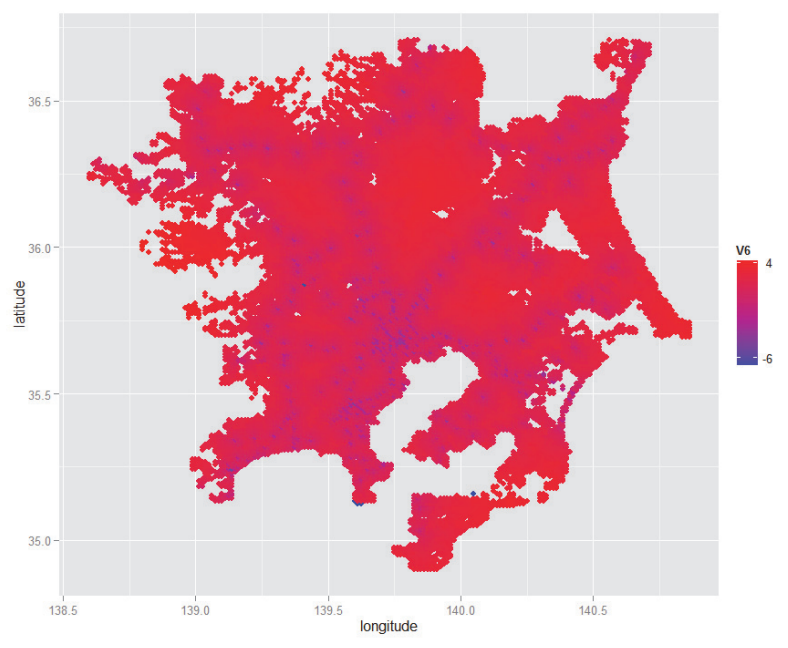

図-6 説明変数 $[\ln ($ 最寄IC距離) $]$ の階級図

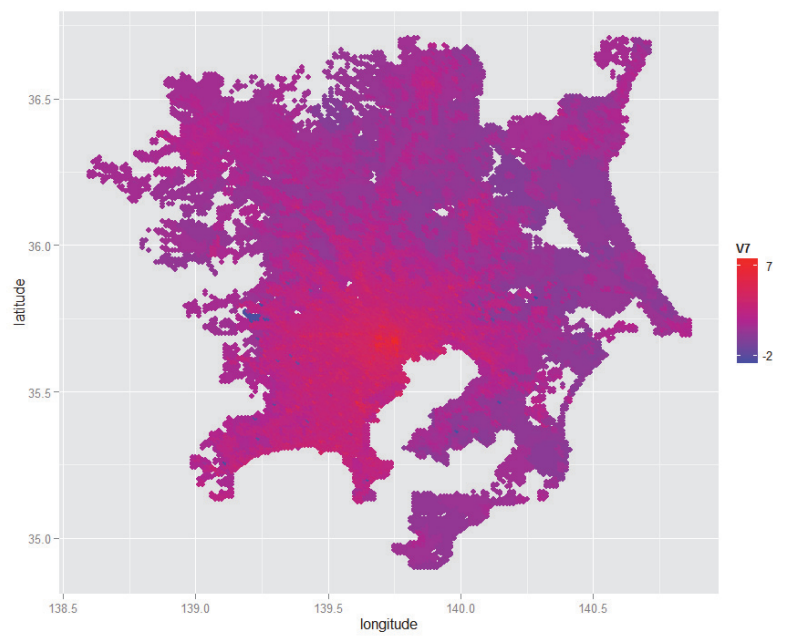

図-7 説明变数 $[\ln ($ (地価) $]$ の階級図

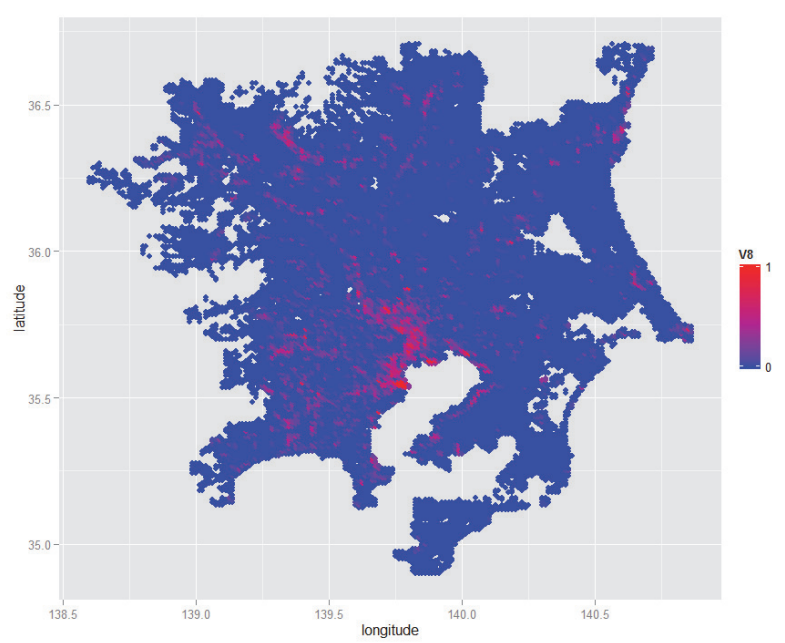

図-8 説明変数 [準工業地域シェア］の階級図

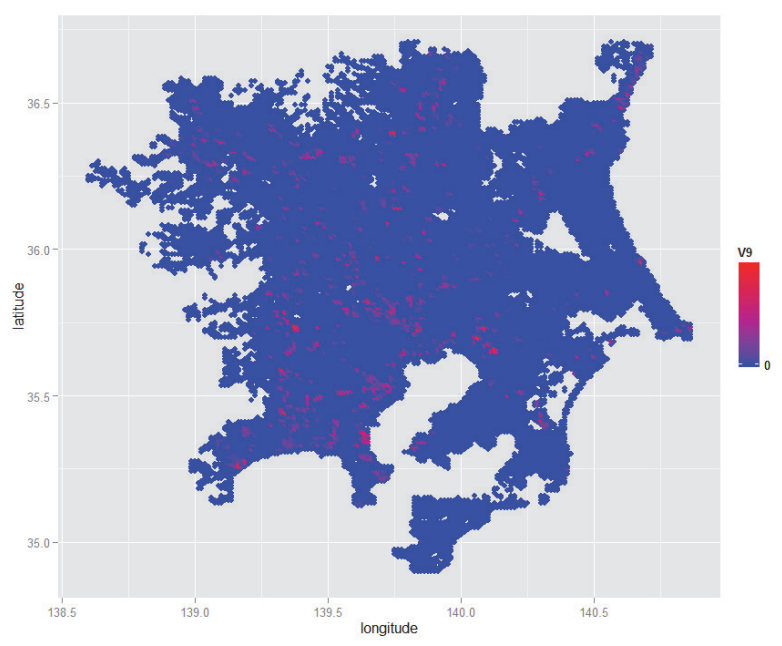

図-9 説明変数 [工業地域シェア $]$ の階級図

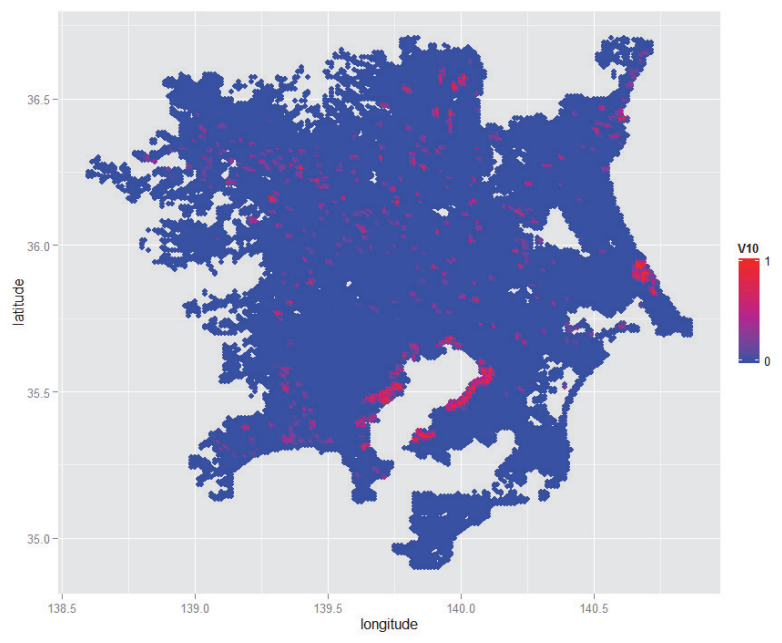

図-10 説明変数 [工業専用地域シェア］の階級図 
表-1 各種立地選択モデルの推定結果 ()内 $t$ 值

\begin{tabular}{|c|c|c|c|}
\hline 変数名 & 全メッシュ MNL & Binary Logit & Binary Probit \\
\hline 1 定数項 & & $-23.105 \quad(-13.0)$ & $\begin{array}{ll}-10.20 \quad(-13.0) \\
\end{array}$ \\
\hline 2 人口密度 [千人 / $\mathrm{km}^{2}$ ] & -0.2160 & $-0.23809(-11.4)$ & $-0.10967(-12.0)$ \\
\hline $3 \ln ($ 労㗢力人口［人］) & 0.7774 & $0.85978 \quad(7.1)$ & $0.35938 \quad(6.7)$ \\
\hline 4ln(全製造業近接性) & $0.01630 \quad(2.2)$ & $0.019611 \quad(2.4)$ & $0.009081 \quad(2.3)$ \\
\hline 5ln(業務地近接性) & $0.5931 \quad(9.5)$ & $0.7411 \quad(11.0)$ & $0.32425 \quad(10.6)$ \\
\hline $6 \ln ($ 最寄 IC 距離 $[\mathrm{km}]$ ) & $-0.08115 \quad(-1.4)$ & $-0.11677 \quad(-1.8)$ & $-0.075355(-2.5)$ \\
\hline $7 \ln ($ (地価［万円］) & $-0.2618 \quad(-3.0)$ & $\begin{array}{ll}-0.35081 \quad(-3.7) \\
\end{array}$ & $-0.12792 \quad(-2.9)$ \\
\hline 8 準工業地域シェア & 2.085 & $2.518 \quad(7.0)$ & $1.3193 \quad(7.1)$ \\
\hline 9工業地域シェア & 1.664 & 1.7654 & 0.90292 \\
\hline 10工業専用地域シェア & 1.483 & 1.5547 & 0.88738 \\
\hline 初期尤度 & -3213.1 & -1638.98 & -1638.98 \\
\hline 最終尤度 & -2792.5 & -1205.39 & -1194.74 \\
\hline 自由度調整済み尤度比 & 0.1281 & 0.2585 & 0.2649 \\
\hline サンプル数 & $\begin{array}{c}328 \\
\text { メッシュ数 : } 17,961\end{array}$ & 18,017 & 18,017 \\
\hline
\end{tabular}

十数秒で問題なくパラメータ推定が行えた.

次に，施設立地の選択肢として，各3次メッシュ（約 $1 \mathrm{~km} \times$ 約 $1 \mathrm{~km})$ に物流施設が「ある」一「ない」の二肢 選択を採用するモデルを考える. このとき，同じメッシ ユに複数の物流施設が立地する場合は，立地数に応じた， 例えば尤度関数の重み付けなどが必要となる. 今回は簡 単のため, 重複数に比例して同じメッシュデータを複数 個追加する方法を採用した. 結果として, 追加されたメ ッシュも含め, 総サンプル数は18,017となった. この二 肢選択モデルには，Binary Logitモデル，Binary Probitモデ ルの両モデルを適用した.

合計3種類のモデル構築結果を表-1にまとめる．興味 深いことに，選択肢数が全く異なるMNLとBinary Logitで 絶対值でも類似した傾向のパラメータが推定されている. これを数值で確認するため, 以下の手順でパラメータの 相対值を求めた.

1) $t$ 值も高く比較的安定している「2人口密度」パラメ ータを1として，3種類の各々の推定パラメータの 相対值を算出

2) MNLの相対值を1として, Binary Logit， Binary Probitの

相対值を更にMNLに対する相対值として変数ごと に算出

その結果が図-11である. $t$ 值が相対的に低い「6 $\ln ($ 最寄 IC距離)」の相対值は1.8を上回っているが，他は概ね 21.3 以下に収まっており, 推定パラメータの傾向が似通って いることが確認できる.

Binary LogitとBinary Probitの推定パラメータの比較では, 理論的には，その比は $\pi / \sqrt{3} \cong 1.81$ になることが知られ ている（例えば参考文献21）の4.2を参照）が，表-1の結 果では，2を超えるパラメータが多いことが分かる．明

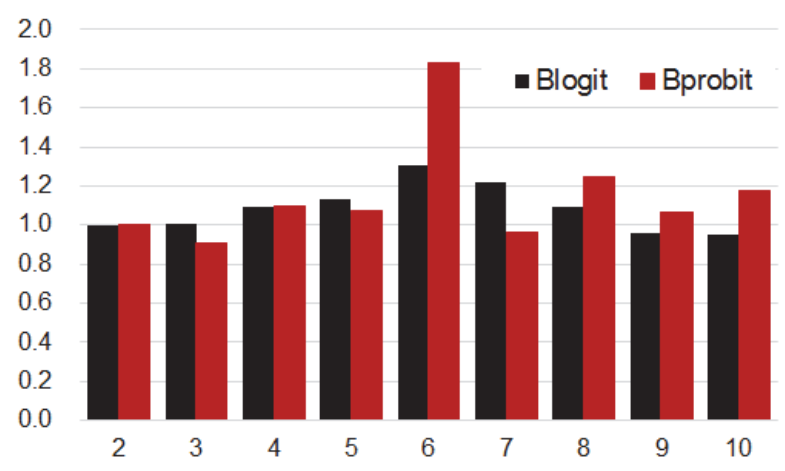

図-11 MNLに対する推定パラメータの相対值 (横軸の番号は表-1の変数番号に対応)

確な理由を特定することはできないが，本データの場合， 二肢選択の「ある」の割合は 328/18017=0.018 と過少であ る. そのため, Gumbel分布と正規分布の裾の部分の密 度関数の形状の相違が，より大きくパラメータ比に反映 されたと思われる。

\section{4. 空間相関を考慮した立地選択モデルの検討}

\section{(1) Spatial Autoregressive Probitモデルの概略}

立地選択モデルでは，隣り合う空間同士に強い相関が 存在することが容易に想像されるし，本分析のように， 比較的空間解像度の細かい3次メッシュを使用する場合 はなおさらであろう。そのため, 立地選択モデルの精度 向上のためには，空間相関を考慮したモデルが必要とな る.

本稿では，空間相関を考慮する手法として，代表的な 手法である, 空間ラグモデル（Spatial lag model: SLM）と 空間誤差モデル（Spatial error model: SEM）を取り上げる 
表-2 距離减衰パラメータおよび隣接メッシュ数と対数尤度の関係

\begin{tabular}{|c|c|c|c|c|c|c|c|}
\hline & \multicolumn{6}{|c|}{ 隣接メッシュ数 } \\
\hline & & 4 & 8 & 12 & 16 & 20 & 24 \\
\hline \multirow{9}{*}{$\begin{array}{l}\text { 減衰 } \\
\text { パラ } \\
\text { メー } \\
\text { タ值 }\end{array}$} & 0 & -1197.3 & -1199.4 & -1199.0 & -1200.1 & -1201.8 & -1201.3 \\
\hline & -0.5 & $\underline{-1195.1}$ & -1197.2 & -1197.7 & -1199.1 & -1200.9 & -1201.4 \\
\hline & -1.0 & $\underline{-1192.5}$ & -1194.2 & -1194.5 & -1196.0 & -1197.4 & -1197.8 \\
\hline & -1.5 & $\underline{-1189.2}$ & -1190.0 & -1189.8 & -1190.8 & -1191.1 & -1191.9 \\
\hline & -2.0 & -1185.9 & -1184.4 & -1184.0 & -1184.3 & -1184.9 & -1184.7 \\
\hline & -2.5 & -1183.6 & -1179.6 & -1179.4 & -1179.0 & $\underline{-1178.6}$ & -1178.9 \\
\hline & -3.0 & -1181.4 & -1177.7 & -1176.1 & -1176.5 & $\underline{-1175.7}$ & -1176.1 \\
\hline & -3.5 & -1181.8 & -1176.7 & -1175.4 & -1175.2 & $\underline{-1174.9}$ & -1175.3 \\
\hline & -4.0 & -1181.5 & -1176.6 & -1176.1 & -1175.8 & $\underline{-1175.5}$ & -1175.9 \\
\hline
\end{tabular}

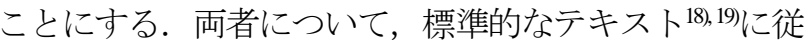
い簡単に記述する.

空間ラグモデルは，近隣の効用項の間に相関を与える 方法で，メッシュ間の空間重み行列を $\mathbf{W}$, 相関係数を $\rho$, 効用を $\mathbf{v}$, 説明変数を $\mathbf{x}$ と定義し, 効用関数を

$$
\mathbf{v}=\rho \mathbf{W} \mathbf{v}+\mathbf{x} \boldsymbol{\beta}
$$

としたときに，これを解いて，

$$
\mathbf{v}=(\mathbf{I}-\rho \mathbf{W})^{-1} \mathbf{x} \boldsymbol{\beta}
$$

なる効用関数を用いる方法である. 一方，空間誤差モデ ルでは，誤差項 $\mathbf{u}$ に同様の空間相関係数 $\lambda$ と空間相関か ら独立な誤差項ベクトル $\varepsilon$ を定義して,

$$
\begin{gathered}
\mathbf{u}=\lambda \mathbf{W} \mathbf{u}+\boldsymbol{\varepsilon} \\
\mathbf{u}=(\mathbf{I}-\lambda \mathbf{W})^{-1} \boldsymbol{\varepsilon}
\end{gathered}
$$

が導かれる. 本分析では，この両者を同時に考慮し，確 率効用関数として以下の式を採用する.

$$
\mathbf{v}=(\mathbf{I}-\rho \mathbf{W})^{-1} \mathbf{x} \boldsymbol{\beta}+(\mathbf{I}-\lambda \mathbf{W})^{-1} \boldsymbol{\varepsilon}
$$

なお，表-1で確認されたとおり，Binary Probitモデルの対 数尤度が, Binary Logitモデルを上回っていたため, 以降 の分析では，空間相関を考慮したProbitモデルを主な分 析手法として用いることにする，また，本稿では，SLM とSEMを併せ持った上記のモデルを Spatial Autoregressive Probit（SAR Probit）モデルと称し，簡単のため，式(7)の 効用の相関係数と誤差の相関係数は分離推定せずに, 共 通の值とする.

\section{（2）各種設定条件と推定精度の関係}

本分析では, SAR Probitモデルのパラメータ推定方法 として標準的なRのライブラリである, spatialprobit ${ }^{20)}$ を用 いる. 同手法では，MCMC推定を行うため，予め標本 数とパラメータ推定精度の関係を検証する必要がある. さらに，空間重み行列の与え方についてもより適切な手 順を検討する.

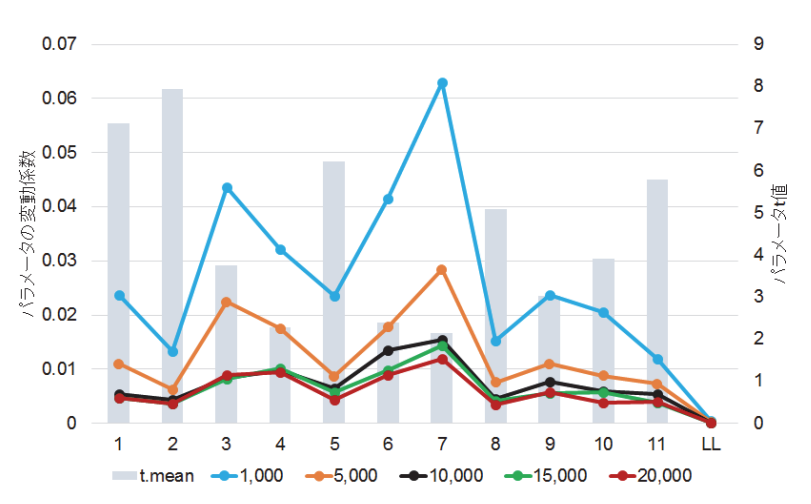

図-12 標本抽出数とパラメータ安定性の関係 (横軸番号は表-1の変数番号に対応. 11は空間相関係数，LLは対数尤度）

\section{a) 標本抽出数とパラメータ安定性について}

まず，空間重み行列には，当該メッシュに空間距離の 近い8メッシュを選び，各メッシュの重み $W_{i j}$ に1/8を割 り当てる方法を採用し，MCMC推定における標本抽出 数と, 推定パラメータの安定性を検証する. なお, bumin回数は1,000回である. 標本抽出数は，1,000 5,000 10,000 15,000 20,000の5通りとし, 各々について，30回のパラメ 一夕推定を行った. その30回のパラメータおよび対数尤 度の変動係数を図-12に示す。

図より, $t$ 值の低い変数のパラメータの安定性は低い が，標本抽出数が10,000程度であれば，全てのパラメー タの変動係数は2\%未満となる.また，その結果は, 15,000や20,000のケースとも大きな相違が認められない ため, 以降の分析では, 標本抽出数は10,000, bum-in回 数は1,000を採用することにする.

b) 減衰パラメータと近隣メッシュ数の影響について

前項では，空間重み行列には，近隣 $\mathrm{R}$ 個のメッシュを 選び，各々について 1/Rの重みを与えていた。 しかし， 距離に応じて相関の度合いが変化すると考える方が自然 である、そのため，以下の手順で Wを推計することを 考える. 


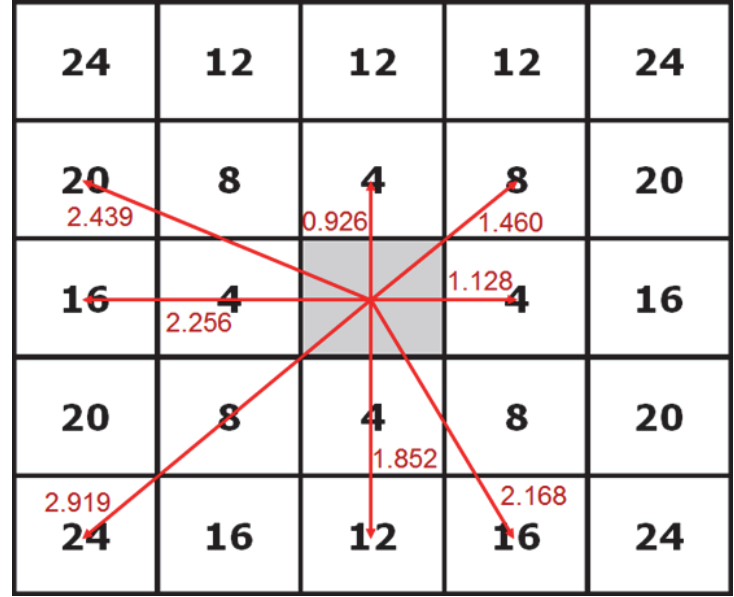

図-13 隣接メッシュ数とその相対位置 (赤字は中心メッシュからの距離 $[\mathrm{km}]$ )

1)分析対象の $i$ 番目メッシュから距離の近い順に, $R$ 個 の隣接メッシュを列挙する，それらメッシュの集合 を $N B_{i}$ とする

2) $j$ 番目隣接メッシュの重みを $\eta_{i j}=\exp \left|\alpha \times D_{i j}\right|$ とする. ここで $D_{i j}$ は $i j$ メシュュ間距離 $(\mathrm{km}) ， \alpha$ は距離减衰 パラメータである.

3)空間重み行列值 $\left(W_{i j}\right)$ を次の式で推計する.

$$
\begin{array}{ll}
W_{i j}=\frac{\exp \left\lfloor\alpha \cdot D_{i j}\right\rfloor}{\sum_{j^{\prime} \in N B_{i}} \exp \left[\alpha \cdot D_{i j^{\prime}}\right]} & \text { if } j \in N B_{i} \\
W_{i j}=0 \quad \text { if } j \notin N B_{i}
\end{array}
$$

結局，この手順は，隣接メッシュについて Logitモデル 式に従う空間重みを設定すること，および，重久行列の 值の行和を1に固定することを意味する.

以上の空間重み行列を, 距離减衰パラメータ $\alpha$ の值, および，隣接メッシュ数の個数の，2つの条件を変化さ せることによる推定精度の変化を検証する．設定した条 件は以下の通りである.

$$
\alpha: 0,-0.5,-1.0,-1.5,-2.0,-2.5,-3.0,-3.5,-4.0 \text { の9通り }
$$

隣接メッシュ数 $R: 4,8,12,16,20,24$ の6通り

なお，隣接メッシュ数と，選ばれるメッシュ位置の関係 は図-13のとおりである。ここでは，例として東京駅の 緯度経度を中心に，3次メッシュの相対位置を描いてい る. 図-13の上段の左右の「12」と，下段の左右の「16 は，平面を仮定すれば同じ距離となるが，実際は球面の ため，メッシュは北側に位置するほど，メッシュ間距離 が縮まるので，12番目には，北側のメッシュが選択され ることになる.

$9 \times 6$ の54通りの推定結果の最終尤度を表-2にまとめ る. 表中，下線を施した数值は，各減衰パラメータ值の 中で最も対数尤度の大きいケースを指寸，結果から，減

\begin{tabular}{|c|c|c|}
\hline 説明変数 & パラメー & $(t$ 值 $)$ \\
\hline 1定数項 & -5.162 & $(-8.0)$ \\
\hline 2 人口密度 $\left[千 人 / \mathrm{km}^{2}\right]$ & -0.06942 & $(-8.6)$ \\
\hline $3 \ln ($ 労働力人口) [人］ & 0.1387 & (3.5) \\
\hline $4 \ln$ (全製造業近接性) & 0.008960 & (2.3) \\
\hline $5 \ln ($ 業務地近接性) & 0.2186 & (7.7) \\
\hline $6 \ln ($ 最寄IC) $[\mathrm{km}]$ & -0.05346 & $(-2.3)$ \\
\hline $7 \ln$ (地価) $\left[\right.$ 万円 $\left./ \mathrm{m}^{2}\right]$ & -0.08464 & $(-2.3)$ \\
\hline 8準工業地域シェア & 0.8350 & $(4.7)$ \\
\hline 9工業地域シェア & 0.7653 & (2.7) \\
\hline 10工業専用地域シェア & 0.5864 & (3.7) \\
\hline 11相関係数 & 0.5045 & (11.9) \\
\hline 初期尤度 & \multicolumn{2}{|c|}{-1638.98} \\
\hline 最終尤度 & \multicolumn{2}{|c|}{-1175.7} \\
\hline 自由度調整済尤度比 & \multicolumn{2}{|c|}{0.2894} \\
\hline サンプル数 & \multicolumn{2}{|c|}{18,017} \\
\hline
\end{tabular}
衰パラメータの絶対值が大きくなるほど，また隣接メッ
表-3 パラメータの推定結果 $(\alpha=-3.5, R=20)$

表-4 Moranの空間相関係数 $(\alpha=-3.5, R=20)$

\begin{tabular}{|l|c|}
\hline \multicolumn{1}{|c|}{ 変数 } & 空間相関係数 \\
\hline 2人口密度 [千人 $\left./ \mathrm{km}^{2}\right]$ & 0.8510 \\
$3 \ln$ (労働力人口) $[人]$ & 0.9722 \\
$4 \ln$ (全製造業近接性) & 0.3852 \\
$5 \ln$ (業務地近接性) & 0.7352 \\
$6 \ln$ (最寄IC) [km] & 0.8219 \\
$7 \ln$ (地価) [万円 $\left./ \mathrm{m}^{2}\right]$ & 0.8808 \\
8 準工業地域シェア & 0.4807 \\
9 工業地域シェア & 0.2915 \\
10 工業専用地域シェア & 0.4824 \\
\hline
\end{tabular}

シュ数が多くなるほど対数尤度が改善されることが分か る. しかし, 減衰パラメータ值も-3以下では対数尤度の 差は小さく, 隣接メッシュ数も12以上では改善度合いは 小さい. 実用上は， $\alpha=-3.0, R=12$ 程度で十分と思われ るが，以降の分析は，表-2で最も対数尤度の大きい， $\alpha=-3.5, R=20$ を用いることにする. なお，その条件下 の推定パラメータ值は表-3の通りである. 表-1と比較し て，尤度比が大幅に改善されており，空間相関を考慮す ることの優位性を確認することができよう.

なお，減衰パラメータと隣接行列の数を決定したため, 確認の為に，各説明変数（図-2～10）の空間的な相関を, 以下のMoran相関係数で推計した. $N$ はメッシュの総数 である.

$$
I=\frac{N}{\sum_{i} \sum_{j} w_{i j}} \frac{\sum_{i} \sum_{j} w_{i j}\left(x_{i}-\bar{x}\right)\left(x_{j}-\bar{x}\right)}{\sum_{i}\left(x_{i}-\bar{x}\right)^{2}}
$$

結果は表-4の通りである. 社会経済属性の空間的な連坦 性から，人口や地価などの相関係数が高く，逆に，存在 位置が限られている，工業系の用途地域シェアなどの相 関係数が低いことが確認される. 


\section{（3）空間相関が推計值に与える影響}

\section{a) 直接効果と合計効果の関連性の確認}

立地選択モデルにおいて，空間相関を考慮することの 一つの意義は，前節で確認したとおり，モデルの推定精 度を向上させることであった，さらに，空間相関を導入 することにより，例えば新規高速道路ICが開設された場 合，IC付近の効用の直接的な増加が，空間相関を通じて 周辺一帯の効用の間接的な向上につながる効果（スピル オーバー効果）が表現可能になる．ここでは表-3のモデ ル結果を用いて，その効果を定量的に検証してみる.

まず，直接的な効用值を以下の式で定義し，この効用 值を「direct項」と称する.

$$
\mathbf{v}_{\mathrm{d}}=\mathbf{x} \boldsymbol{\beta}
$$

次に，空間相関を考慮し，他のメッシュの効用が及ぼす 効果と, 上記direct項も含めた合計の効果は次式で推計さ れるので，これを「total項」と称する.

$$
\mathbf{v}_{\mathbf{t}}=(\mathbf{I}-\rho \mathbf{W})^{-1} \mathbf{x} \boldsymbol{\beta}
$$

まず，表-3のパラメータ推定に用いたデータと推定パラ メータにより，direct項と total項を推計し，合計18,017メ ッシュの各々の頻度分布を図-14に示す。空間相関の効 果で, total項は, direct項に比して分散が大きく, 効用值 が互いに滲みだす様子を想像することができる.

両者の散布図が図-15であるが，同様に，縦軸にとつ たtotal項側のバラツキが大きくなる傾向が確認される. なお， total項の効用值がdirect項より相対的に小さくなる のは，本ケースの場合，殆どのdirect項の効用值が負值で あることに起因する。

次に，両効用值の空間的な分布について考察する.ま ず，図-16から，物流施設の立地効用は，臨海部と，供 用されている圈央道西部周辺，そして外環道の埼玉地域 などで高い值を示していることが分かる。これに空間相 関も加味したtotal項をみると，総じて隣り合うメッシュ

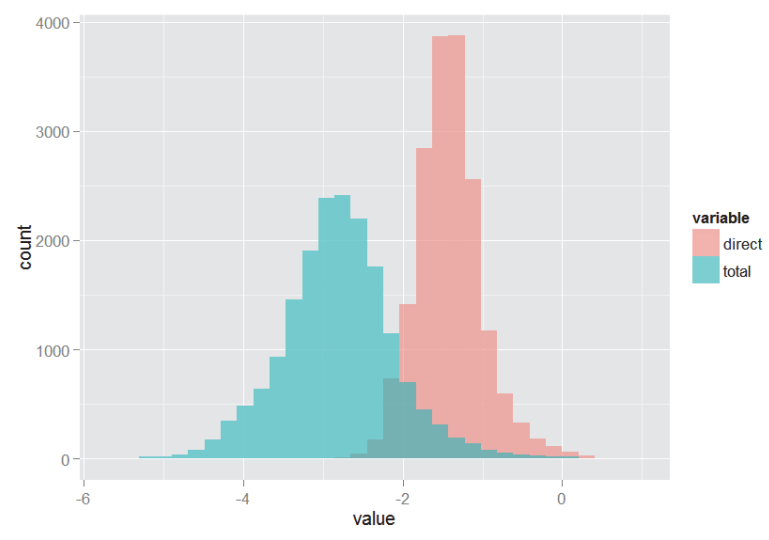

図-14 direct項とtotal項の頻度分布（横軸は効用の值）
間の大小関係が緩和された結果となっており，空間的な 相互作用が㗢いていることが理解できよう.

\section{b) 交通条件変化に関する感度分析}

次に，現在事業が予定されている対象地域の高速道路 ネットワークが完成した将来LOSを設定し，同様に表-3 のモデルにより予測值による感度分析を試みる．設定し た将来ネットワークは図-18のとおり，いわゆる三環状

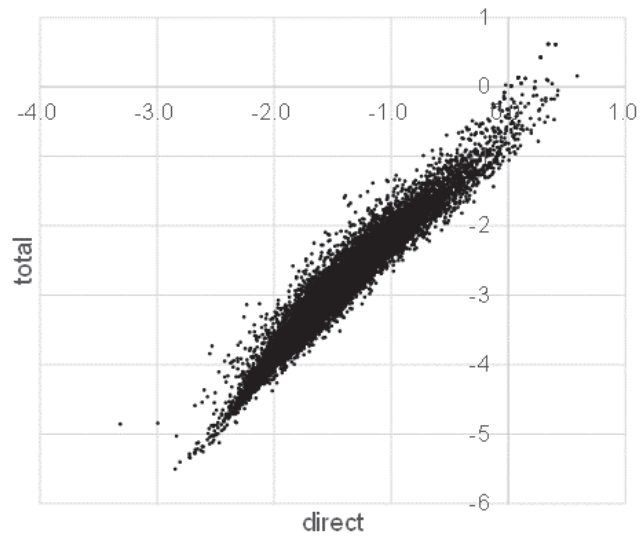

図-15 direc項（横軸）とtotal項（縦軸）の散布図
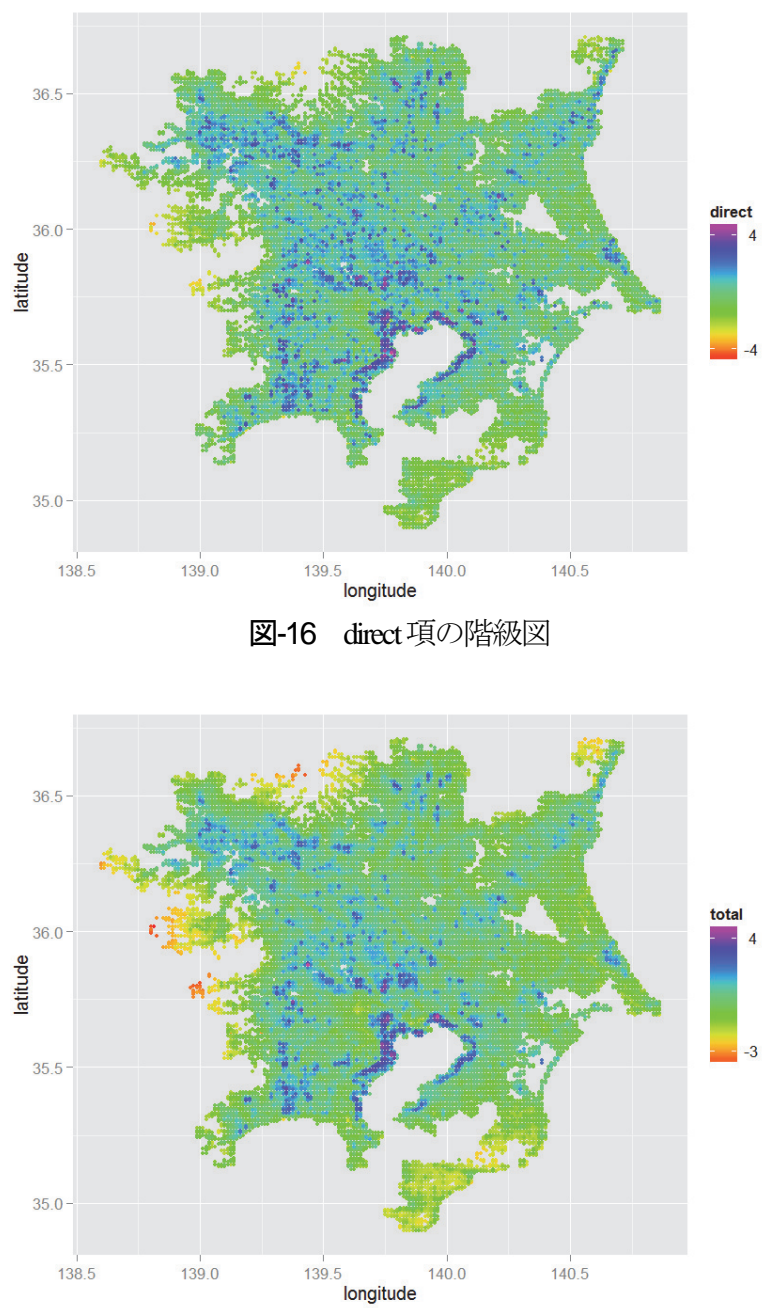

図-17 total 項の階級図 


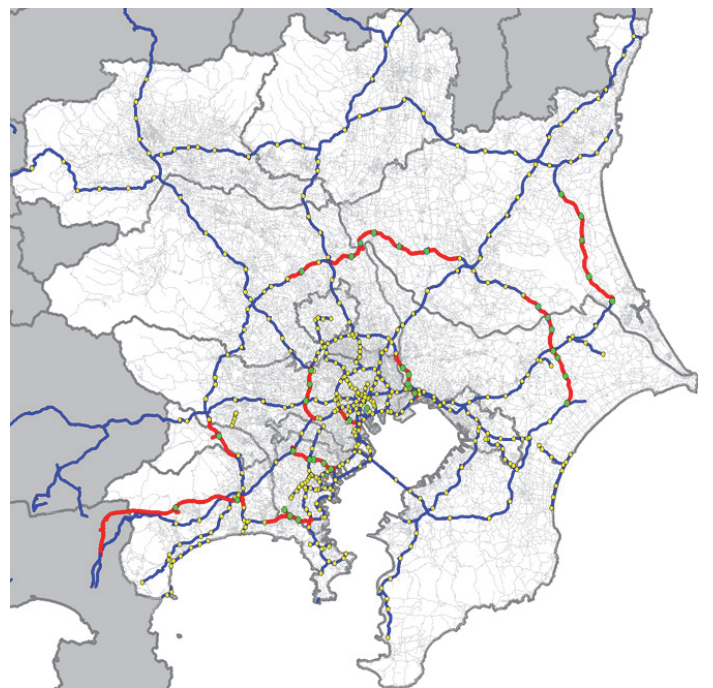

図-18 設定した将来道路ネットワーク

[赤線が新規路線，緑丸は新規ICを表す］

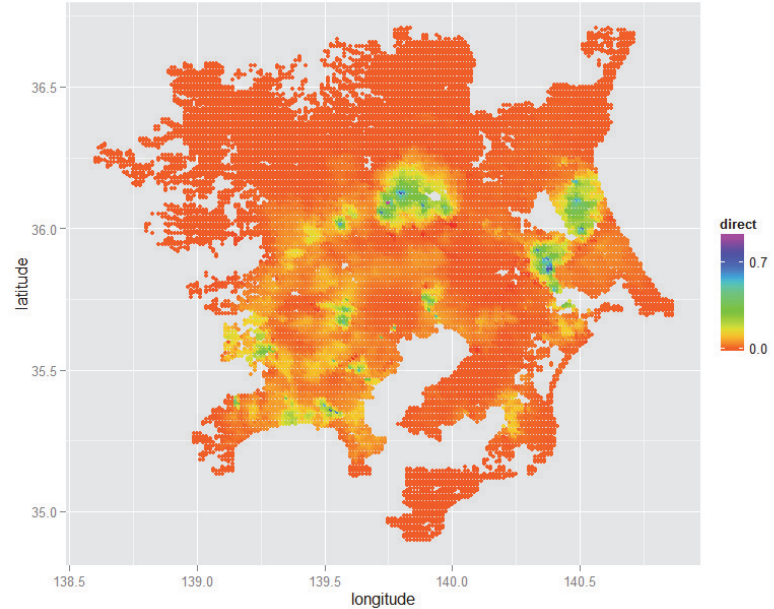

図-19direct項の基準化值の将来 LOS による変化值の階級図

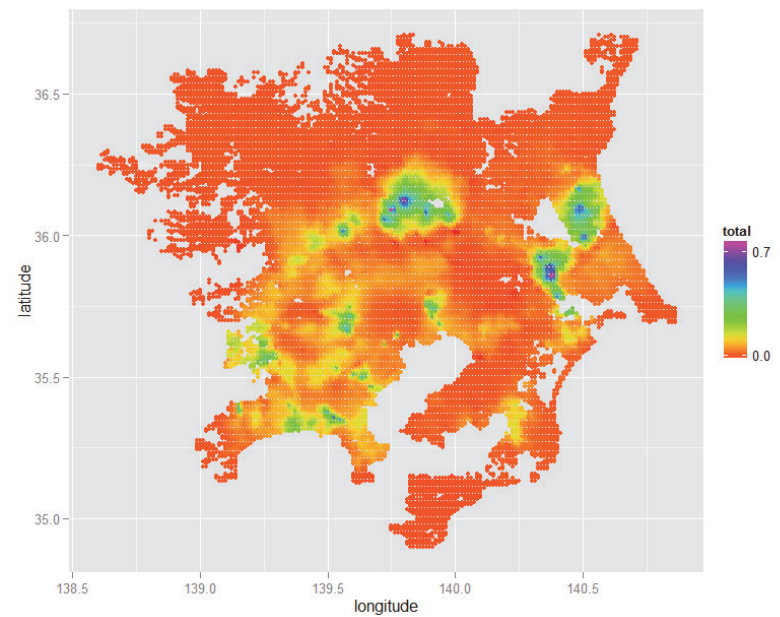

図-20 total 項の基準化值の将来 LOSによる変化值の階級図

の概成や，新東名高速道路，東関東自動車道水戸線など の開業を想定している。

なお，推計される効用值は図-14で確認されたように， direct項と total項では平均も分散も異なる。ここではLOS 条件の変化による相対的な効用の変化を確認寸るため, direct項もtotal項も，それぞれまず推計された現況の効用 值を $N(0,1)$ に標淮化する. さらに，将来の効用值も，現 況の効用值の標準化に用いた平均と分散を用いて，同様 に標準化することとした.

推計結果（図-19）を見ると，埼玉県から茨城県にか けて新たに開業が予定される圈央道のIC付近で立地効用 が大きく増加することが見て取れる，なお，紙面の都合 上，詳細は省くが，成田空港や東関東自動車道水戸線周 辺で標淮化值の変化が大きいが，絶対值は相対的に小さ いことを付記しておく.

図-20により，空間相関も考慮したtotal項の標準化值の 変化を確認すると，ここまで紹介してきた結果と同様に， 効用の変化率が緩やかになっていることが分かる．さら に，効用值の大きな箇所（圈央道埼玉県区間のIC付近な ど）では，相乗効果のために，より一層，当該箇所の効 用值が高まっている様子も伺うことができる.

\section{(4) Mixed Logitモデルとの比較}

前節までは，立地選択モデルにはProbitモデルを採用 していたが，誤差構造を柔軟に取り込むことが可能な，

Mixed Logitモデルでも, 空間相関を考慮したモデル構築 は可能である．参考までに，その方法と結果の概略を紹 介寸る.

Mixed Logitモデルの場合は，式(7)の誤差項 $\boldsymbol{\text { として正 }}$ 規乱数を発生させ,

$$
\mathbf{u}=(\mathbf{I}-\lambda \mathbf{W})^{-1} \boldsymbol{\varepsilon}
$$

で与えられる相関を持った誤差項 $\mathbf{u}$ （サンプル数 $\times$ 選 択肢数）の $r$ 番目標本の要素を $u_{n i}^{r}$ と寸れば, 標本数を NRとして,

$$
P_{n 1}=\frac{1}{N R} \sum_{r=1}^{N R} \frac{e^{V_{n 1}+u_{n 1}^{r}}}{e^{V_{n 1}+u_{n 1}^{r}}+e^{V_{n 2}+u_{n 2}^{r}}}
$$

でn 番目サンプルの1番目選択肢の選択確率を得ること ができる. パラメータ推定は, 式(13)を用いた最尤法に よるが，計算効率化のために，本分析では正規乱数の発 生にはHalton sequence を適用し，かつHalton sequence の系 列相関を取り除くため, 一様乱数を用いてスクランブル をかけている. 距離重み行列の設定は表-3の結果と同じ にし，標本数として1,000を採択した場合のパラメータ 推定結果の例を表-5にとりまとめる.

空間相関の扱い方として, 前節のSAR Probit モデル同 様, SLMとSEMで共通の相関係数を有するモデル（表中 のModel 1) に加えて, 式(7)の通り, 効用の空間相関係 数 $(\rho)$ と, 誤差項の空間相関係数 $(\lambda)$ を分離したモ デル（表中のModel 2）も試み, 推定結果にとりまとめ た. 表-3とも比較すれば分かる通り, 尤度比は向上し, 特に相関係数を分離したケースで大きく説明力が高まっ 
ている. 尤度比の向上とともに, 推定パラメータの絶対 值も大きくなる傾向にあり， Model 2 では，SAR Probit の 3倍程度の大きさになっている.

以上より，空間相関を考慮するモデルとして， Mixed Logit モデルの有効性を確認寸ることができた．しかし， 本モデルの推定には莫大な計算時間を要する．例えば, 標準的なPC (CPU : Intel Corei7-3930K3.20GHz, RAM : 32 G）では，解の収束におよそ一週間を要した。これは Mixed Logitモデルの場合は，式(7)から理解されるとおり， 行列数が18,017の正方行列の逆行列計算が避けられない ためである．距離重み行列自体はいわゆる疎（sparse） 行列であり， O以外の要素の割合は，20/18017=0.0011 と， 0.11\%程度である．そのため，Rのコードでも疎行列に 対応した逆行列計算ライブラリを用いているが，逆行列 は完全に密（0の要素は存在しない）であったため, 十 分な計算時間の短縮効果を得ることはできなかった.

モデル推定精度は高いものの, 計算効率からは現時点で は実用的とはみなせないので，本稿ではMixed Logit モデ 儿結果は比較対象の参考例として紹介寸るにとどめる. パラメータ推定方法の劇的な高速化が実現できれば，実

表-5 MixedLogitモデルの推定結果 $(\alpha=-3.5, R=20)($ )内 $t$ 值

\begin{tabular}{|c|c|c|}
\hline 説明変数 & Model 1 & Model 2 \\
\hline 1 定数項 & $\begin{array}{l}-9.674 \\
(-80)\end{array}$ & $\begin{array}{l}-20.28 \\
(-64)\end{array}$ \\
\hline 2人口密度 ～ & -0.1082 & -0.2072 \\
\hline$\left[\right.$ 千人 $\left./ \mathrm{km}^{2}\right]$ & $(-7.5)$ & $(-6.6)$ \\
\hline $3 \ln ($ 労働力人口) & 0.2984 & 0.6958 \\
\hline [人 & (5.2) & (4.8) \\
\hline $4 \ln$ (全製造業近接性) & $\begin{array}{l}0.006904 \\
(1.2)\end{array}$ & $\begin{array}{l}0.01401 \\
(1.3)\end{array}$ \\
\hline $5 \ln$ (業務地近接性) & $\begin{array}{l}0.4464 \\
(8.4)\end{array}$ & $\begin{array}{l}0.7721 \\
(7.5)\end{array}$ \\
\hline $6 \ln$ (最寄IC) & -0.07174 & -0.1381 \\
\hline$[\mathrm{km}]$ & $(-2.2)$ & $(-2.0)$ \\
\hline $7 \ln$ (地価) & -0.2775 & -0.4534 \\
\hline$\left[\right.$ 万円 $\left./ \mathrm{m}^{2}\right]$ & $(-5.1)$ & $(-4.4)$ \\
\hline 8準工業地域シェア & $\begin{array}{l}0.9667 \\
(3.9)\end{array}$ & $\begin{array}{l}2.163 \\
(4.0)\end{array}$ \\
\hline 9工業地域シェア & $\begin{array}{l}1.359 \\
(3.2)\end{array}$ & $\begin{array}{l}2.121 \\
(2.6)\end{array}$ \\
\hline 10工業専用地域シェア & $\begin{array}{l}0.8325 \\
(4.1)\end{array}$ & $\begin{array}{l}1.584 \\
(3.6)\end{array}$ \\
\hline 11 相関係数 & $\begin{array}{l}0.7528 \\
(24.2)\end{array}$ & \\
\hline 12 効用相関係数（ $\rho)$ & & $\begin{array}{l}0.4914 \\
(6.2)\end{array}$ \\
\hline 13 詔差相関係数（ $\lambda)$ & & $\begin{array}{l}0.8765 \\
(53.1)\end{array}$ \\
\hline 初期尤度 & -1638.98 & -1638.98 \\
\hline 最終尤度 & -1138.2 & -1118.1 \\
\hline 自由度調整済尤度比 & 0.2989 & 0.3105 \\
\hline サンプル数 & 18,017 & 18,017 \\
\hline
\end{tabular}

用モデルの一つとして利用可能と想像されるが，今後の 課題として後続研究に託したい.

\section{5. おわりに}

本分析では，第五回東京都市圈物資流動調査結果を用 いて，各種の物流施設の立地選択モデルの比較検討を行 った．特に，空間ラグモデルと空間誤差モデルを導入す ることにより, 従来以上の説明力を有するモデル構築が 可能であることを示すことができた，さらに，空間重み 行列の距離减衰パラメータや，隣接メッシュ数などの基 礎的な入力条件とモデル精度との関係も明らかにするこ とができた.ここで扱われている物流施設立地選択モデ ルと同様の分析方法は，東京都市圈物資流動調查の解析 手法としても用いられており, 本成果を実務に有意に反 映させることも可能であり，一定の実用性の向上につな がることが期待される.

その一方で, 分析データのメッシュ数が多大であり, 実用的なモデル構築には，計算時間の短縮や，使用メッ シュの効率的なサンプリングなど，克服すべき課題も少 なからず存在する．また，昨今の新規供用IC周辺の盛ん な物流施設立地動向を鑑みれば，第四回と第五回の東京 都市圈物資流動調查の二時点比較分析も，重要なテーマ となろう。

末筆ではあるが，データを提供頂いた東京都市圈交通 計画協議会に謝意を表する，なお，本分析は科学研究費

(基盤研究 (C) 「三環状概成を迎える東京都市圈の物 流施設立地に関わる多時点分析」）の一部として実施さ れたことを付記しておく.

\section{付録（補注）}

メッシュの地価データの作成手順

（東京都市圈交通計画協議会資料より）

1) 3次メッシュごとに, 用途地域別の公示地価の平均值 を算出する.

2) 3次メッシュ内に，当該用途地域がない場合は，その メッシュが主に所在する市区町村全体の, 当該用途地 域の公示地価平均值を用いる. その值も存在しない場 合は，主に所在する都県全体の当該用途地域の公示地 価平均值を用いる

3) 推計されたメッシュ別・用途地域別平均地価を用いて, 次表の優先順位に基づき，メッシュ平均地価を算出す る. 


\begin{tabular}{|c|c|c|}
\hline 優先 & 条件 & 算出方法 \\
\hline 1 & $\begin{array}{l}\text { 工業系用途地域 } \\
\text { のあるメッシュ }\end{array}$ & $\begin{array}{l}\text { 用途地域別 (準工業, } \\
\text { 工業, 工業専用) 面積 } \\
\text { シェアで加重平均 }\end{array}$ \\
\hline 2 & $\begin{array}{l}\text { 商業系用途地域 } \\
\text { のあるメッシュ }\end{array}$ & 商業地域の平均地価 \\
\hline 3 & $\begin{array}{l}\text { 住宅系用途地域 } \\
\text { のあるメッシュ }\end{array}$ & 住宅地域の平均地価 \\
\hline 4 & $\begin{array}{l}\text { 市街化調整区域 } \\
\text { のあるメッシュ }\end{array}$ & $\begin{array}{l}\text { 市街化調整区域の平均 } \\
\text { 地価 }\end{array}$ \\
\hline 5 & その他 & その他地域の平均地価 \\
\hline
\end{tabular}

\section{参考文献}

1) Weber, A. and Friedrich, C. J.: Alfred Weber's Theory of the Location of Industries, PAIS International, 1929.

2) McFadden, D.: Modelling the choice of residential location, In A. Karlquist et al. (eds.), Spatial Interaction Theory and Planning Models, Amsterdam: North-Holland, 1978.

3) Waddell, P.: UrbanSim: Modeling urban development for land use, transportation, and environmental planning, Journal of the American Planning Association, Vol. 68, Issue 3, pp. 297-314, 2002.

4) Moeckel, R.: Simulation of firms as a planning support system to limit urban sprawl of jobs, Environment and Planning B: Planning and Design, Vol. 36/5, pp. 883-905, 2009.

5) 萩野保克, 遠藤弘太郎：立地選択モデルを用いた東 京都市圈における物流施設の立地ポテンシャル分析, 土木計画学研究・論文集, Vol. 24, pp. 103-110, 2007.

6) Nguyen, C. Y. and Sano, K.: Location choice model for logistic firms with consideration of spatial effects, Transportation Research Record: Journal of the Transportation Research Board, Vol. 2168/1, pp. 17-23, 2010.

7) 萩野保克, 遠藤弘太郎, 兵藤哲朗：土地需給バラン スを考慮した施設立地モデルによる東京都市圈の物 流施設配置分析, 都市計画論文集, Vol. 46/3, pp. 859864, 2011.

8) Woudsma, C., Jensen, J. F., Kanaroglou, P. and Maoh, H.: Logistics land use and the city: A spatial-temporal modeling approach, Transportation Research Part E: Logistics and Transportation Review, Vol. 44/2, pp. 277-297, 2008.

9) van den Heuvel, F. P., De Langen, P. W., van Donselaar, K.
H.: and Fransoo, J. C.: Spatial concentration and location dynamics in logistics: the case of a Dutch province, Journal of Transport Geography, Vol. 28, pp. 39-48, 2013.

10) Verhetsel, A., Kessels, R., Goos, P., Zijlstra, T., Blomme, N. and Cant, J.: Location of logistics companies: A stated preference study to disentangle the impact of accessibility, Journal of Transport Geography, Vol. 42, pp. 110-121, 2015.

11) 堤盛人, 瀬谷創：土木計画における応用空間統計学 の可能性, 土木学会論文集 D3, Vol. 68, No. 5, pp. 1_11_20, 2012.

12) Miyamoto, K., Vichiensan, V., Shimomura, N. and Páez, A.: Discrete choice model with structuralized spatial effects for location analysis, Transportation Research Record: Journal of the Transportation Research Board, Vol. 1898/1, pp. 183-190, 2004.

13) 前掲 6) と同じ

14) Bhat, C. R. and Guo, J. Y.: A mixed spatially correlated logit model: formulation and application to residential choice modeling, Transportation Research Part B: Methodological, Vol. 38/2, pp. 147-168, 2004.

15) Sener, I. N., Pendyala, R. M. and Bhat, C. R.: Accommodating spatial correlation across choice alternatives in discrete choice models: an application to modeling residential location choice behavior, Journal of Transport Geography, Vol. 19, pp. 294-303, 2011.

16) Ibeas, Á., Cordera, R., dell’Olio, L. and Coppola, P.: Modelling the spatial interactions between workplace and residential location, Transportation Research Part A: Policy and Practice, Vol. 49, pp. 110-122, 2013.

17) 第 5 回東京都市圈物資流動調查結果【速報版】, 東京 としけん交通だより, Vol. 27, 2014.11. https://www. tokyo-pt.jp/publicity/file/vol27.pdf

18) LeSage, J. and Pace, R. K.: Introduction to Spatial Econometrics, CRC Press, 2009.

19) 瀬谷創, 堤盛人：空間統計学, 朝倉書店, 2014 .

20) Wilhelm, S. and de Matos, M. G.: Estimating spatial probit models in R, The R Journal, Vol. 5/1, pp. 130-143, 2013. http://journal.r-project.org/archive/2013-1/wilhelm-matos. pdf

21) Ben-Akiva, M. and Lerman, S.: Discrete Choice Analysis: Theory and Application to Travel Demand, The MIT Press, 1985.

(2015. 5. 19 受付) 


\section{ANALYSIS OF LOGISTICS FACILITY LOCATION CHOICE \\ IN THE TOKYO METROPOLITAN AREA USING DISCRETE CHOICE MODELS WITH SPATIAL CORRELATION}

\section{Tetsuro HYODO, Takanori SAKAI and Kazuya KAWAMURA}

There has been a noticeable development of logistics facilities along the newly constructed circumferential expressway in the Tokyo Metropolitan Area, suggesting a strong association between the access provided by the roadway system and the locations of logistics facilities. As such, the development of analytical tools that can capture the complex relationships between the logistics facility location choice and locational attributes including spatial dependency is an important research endeavor. This paper aims to examine the effectiveness of alternative formulations of discrete choice models, including spatial autoregressive (SAR) probit and mixed logit models, for the analysis of logistics facility locations in the Tokyo Metropolitan Area.

The data from the 2013 Tokyo Metropolitan Freight Survey (TMFS) were used to compare the characteristics of several models. To apply the model, the Tokyo area was partitioned into approximately 18,000 $1 \mathrm{~km}$ by $1 \mathrm{~km}$ grids. The independent variables include population density, employment, land price, land use, access to interchanges, and others. We estimated the location choice model with spatial correlations including Spatial Lag Model (SLM) and Spatial Error Model (SEM) with both probit and mixed-logit approaches. We also investigated the effects of different formulations of the spatial weight matrix on the models' performances. Our investigation found that inclusion of the spatial correlation terms improves the fit of the location choice model considerably. The mixed-logit model that incorporates both spatial lag and spatial error terms produced the best results. However, we believe the amount of time required for the estimation of the model may discourage practical application. On the other hand, the spatial autoregressive probit model can be within the reach of advanced practitioners. 